\title{
ENVIRONMENTAL RESIDUES AND CONTAMINANTS
}

\author{
Nicolae Suvorov ${ }^{1}$, Alina Stancu ${ }^{2}$
}

\begin{abstract}
With the globalisation and diversification of supply on agri-food market, recent decades have been brought issues and risks to human health due to increasing content of chemical residues from agriculture. Identifying of contamination risks at each agri-food chain stage or high level of traceability is extremely important, having in mind that is not only the production stage determining the occurrence of chemical residues within the food. Initial step in eliminating risks related to the contamination of agri-food products with harmful substances is awareness towards their limitation and tolerated daily doses in human consumption. The paper aims to analyse the main groups of contaminating compounds, thus creating a classification according to their level of toxicity and effects on humans.
\end{abstract}

Key words: food contaminants, food safety, toxicology, environmental contaminants, ecological damage.

JEL'3 : I10, L66, Q15

\section{Introduction}

The direct impact of industrial intensification and technological development linked to population growth is chemical contamination with the residues that end up being consumed in a large scale, affecting the negative health effects. Human society has been producing and consuming a very wide range of chemicals, while some of them are toxic. Chemical contaminants cause ecological damages far away from the place their origin, being transported over long distance in air and water, as well as they are susceptible to changes in toxicity and chemical structure (Schmitt, 1998). Public opinion is increasingly discussing how pesticides used in conventional agriculture are dangerous to human health, whether they come directly from plants or are found in animal tissues as chemical residues from contaminated feed. It is well known that the sources of contamination are multiple.

1 Nicolae Suvorov, Ph.D. Student, Bucharest University of Economic Studies, Pata Romana no. 6, 010374 Bucharest, Romania, Phone: +40740474 653, E-mail: suvorov.nicolae@gmail.com

2 Alina Madalina Stancu, Ph.D. Student (corresponding author), Bucharest University of Economic Studies, Piata Romana no. 6, 010374 Bucharest, Romania, Phone: +40 735361 478, E-mail: stancualina13@stud.ase.ro

3 Article info: Review Article, Received: 24 ${ }^{\text {th }}$ April 2021, Accepted: $12^{\text {th }}$ May 2021. 
They are related to the natural circulation and balance of agricultural ecosystems, while the water, air and soil can transmit various hazardous compounds to plants or animals. The professional literature, scientific studies, public institutions and policy makers are raising the issue of reducing the risks associated with the use of pesticides and other potentially carcinogenic contaminants in agriculture (FMI, 1990). Although ensuring a food safety is usually easy to follow process, food safety is facing many challenges due to the many potential contamination risks at all stages of the agri-food supply chain (Radovanovic, 2011). A World Health Organization (WHO) study deeply considers the current situation regarding the negative effects of naturally occurred environmental and chemical contaminants used in agriculture on human health, pointing out that every year around 200 different diseases are caused by the ingestion of food contaminated with viruses, parasites and bacteria. In other words, around 600 million people become ill, or 420 thousands of them globally die each year from this problem. The situation is even worse with children under age of 5 year, where $40 \%$ of them are affected by the negative effects of food contamination, while the annual death toll reaches 120 thousands. For example, diarrheal is annually responsible for 230 thousands of deaths, previously affecting 550 million of people (WHO, 2020). Compared to illnesses caused by environmental contamination, ingestion of chemical residues from used pesticide is very limited, although the population is exposed to a huge number of toxicological factors and substances (Ames et al., 1996). Plants' natural defence mechanism that is producing toxins in order to control diseases and pests could cause food contamination, resulting later the illness from natural sources after human ingestion (Ames et al., 1990). In addition to mentioned problems in the food safety sector, genetically modified organisms (GMO) make the situation much worse as several studies show serious health consequences caused by their consumption (Swanson et al., 2014). Internal gene alterations caused by GMO consumption could lead to various cancers or they can also instil resistance to antibiotics (Acosta, Chaparro, 2008). Contrary to that, some laboratories after investigating these issues report that there are no major differences between the consumption of GMO and non-GMO food-products, so they would not pose a health concern (Bernstein et al., 2003). Coming back to the volume of contaminants contained in food, the natural outweigh the artificial ones. Ratio between natural toxicity of plants as a part of their defence system and concentration of pesticides or synthetic substances in food products is thousands or a million versus billion. So, natural, environmentally-derived contaminants exceed the presence of synthetic ones (Zeiger, 1997). 


\section{Research Method}

According to interdependency between the production factors, agri-food market and consumers, it is important to stress the importance of food traceability and identification of potential risks that could unbalance the smooth running of food chain. Detailed analysis of each stage is absolutely necessary in order to find all factors that can impact the food quality and safety. The production units (generally farms) are the starting segment of agri-food chain, segment with concentration of cause-effect factors that influence the next steps along production chain. This paper represents a literature review on environmental contaminants. It is designed to answer the next questions:

1. What are the main groups of environmental contaminants that can affect food quality and safety?

2. What negative effects do they have on human body?

3. What could be done in order to mitigate the risks caused by food contamination with these compounds?

The research results are summarised, analysing the certain groups of chemical and biochemical compounds that more or less affect the food safety, i.e. presenting the risks towards their consumption by humans.

The analytical framework for the research was developed on the PICO criteria (Population, Intervention, Control and Outcomes). PICO concept represents widely used approach for shaping the primary research question and eligible criteria. It breaks the research question into the four criteria fostering the identification of crucial information. The global population was considered from the context of ensuring food safety and identifying natural or environmental contaminants that may affect the quality of consumed food, as well as the content of harmful substances within it (Aslam, Emmanuel, 2010; Young et al., 2020). Besides, it was used the desktop research method, comparative analysis and deduction.

Search and qualitative analysis of available scientific and professional studies and articles were done through the mostly used scientific and institutional databases. The main paper objective is to identify the leading environmental contaminants and their effects on human health, trying to find effective solutions in considered risks reduction. Among the suggestions for mitigation the negative effects of food contamination is underlined the permanent monitoring of overall agri-food chain, respecting the predefined production, processing, storage, packaging, transportation, distribution and marketing standards and principles. 


\section{Results and Discussions}

Environmental contaminants form a group of substances that in spite the different chemical structure have common characteristics in their use. Contaminants are persistent and stable substances which occur in environment and bio-accumulate over time in the food chain. After certain structural changes it could come to increase in their toxicity. In order to facilitate the control of human safety, the concept of persistent organic pollutants (POPs) has been implemented (Table 1.). They are heterogeneous group man-produced chemicals (Ljunggren et al., 2014). Currently are known several thousands of POP chemicals, usually originated from certain family of chemicals. They are highly persistent in environment, having long halflives, usually from several days up to few decades. In practice, they are generally water-hating and fat-loving chemicals (Jones, De Voogt, 1999).

Table 1. Persistent organic pollutants (POPs)

\begin{tabular}{|c|c|}
\hline Pesticide & Industrial toxins \\
\hline 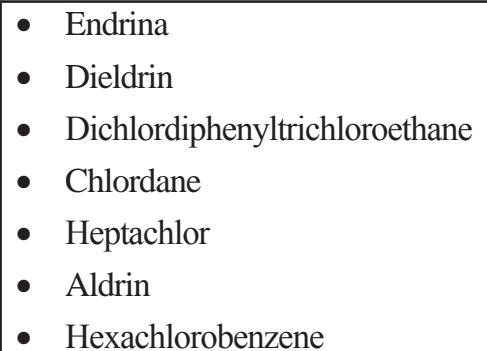 & $\begin{array}{ll}\text { - } & \text { Dioxin } \\
\text { - } & \text { Furani } \\
\text { - } & \text { Polychlorinated biphenyls }\end{array}$ \\
\hline
\end{tabular}

Source: EFSA, 2018.

POPs have the following properties:

- Globally they are transmitted through a process known as the lacustrine effect. POPs released in certain region can be transported to other considerably distant regions throughout the deposition or evaporation processes (Alharbi et al., 2018);

- They persist in environment for a long time, being very stable compounds (Ashraf, 2017);

- They can be bio-accumulated within the natural food chains, i.e. they are taken up by living organisms through deposition in fatty tissues;

- They are expressing high degree of toxicity that could cause negative effects on humans, such as malformations, illnesses and even death. Specific effects lead to the risks of hypersensitivity, allergies, cancer, damage of the nervous system, as well as disorders of the reproductive system, or weakening of immune system. POPs are also causing endocrine disruption affecting both current and future generations (Gaur et al., 2018); 
- They do not form intermediate species, and they are metabolically stable in meat foods.

Contaminants are mostly transferred and accumulated from the environment into the food chain through the aquatic or terrestrial pathways (NRC, 2000). In water they are accumulating and later transferring directly through the fish or indirectly throughout the consumption of other water living organisms. Contaminants present in the soil are entering the human body through the consuming the animal and plant products, while the use of agri-chemicals (Table 2.) can lead to contamination of the overall food chain.

Table 2. Main groups of pesticides

\begin{tabular}{|l|l|}
\hline \multicolumn{1}{|c|}{ Pesticide } & \multicolumn{1}{c|}{ Controlled pests } \\
\hline Ovicide & Insect eggs and spiders \\
\hline Acaricide & Spiders \\
\hline Insecticides and insect fungicides & Insects, fungi, bacteria \\
\hline Growth promoters & Stimulates plant growth \\
\hline Fungicide & Microscopic fungi \\
\hline Rodenticide & Rodent \\
\hline Herbicide & Weeds and parasitic plants \\
\hline Nematocide & Worms \\
\hline
\end{tabular}

Source: EFSA, 2018.

\section{Industrial contaminants}

Most industrial contaminants are usually end products or intermediates in certain industrial processes, being complex, organometallic or inorganic substances (Dougherty et al., 2000). In next table (Table 3.) are shown some of industrial contaminants found in food, having the toxic potential on humans.

For example, contamination of the human body with dioxin produces serious health effects such are immune toxicity, dermal toxicity, carcinogenicity, reproductive abnormalities and endocrine disruption. Poisoning effects with dioxin are long term, while according to Biology Department of Woods Hole Oceanographic Institution from USA they can be accumulated within the seven years (Hahn, 2002). The sources of contamination could be previously contaminated feed stuffs, recently flooded pastures (by contaminated water), certain industrial processes and waste effluents. 
Table 3. Contaminants of industrial origin

\begin{tabular}{|l|l|l|}
\hline \multicolumn{1}{|c|}{ Container } & \multicolumn{1}{|c|}{ Source } & \multicolumn{1}{c|}{ Food } \\
\hline Arsenic & Melting operations & Meat products \\
\hline Cadmium & $\begin{array}{l}\text { Melting operations, } \\
\text { communal water }\end{array}$ & Cereals, vegetables \\
\hline Pewter & Preserves & Canned products \\
\hline Alkyl mercury compounds & Manufacture of acetaldehyde, dressing & Cereals \\
\hline Dibenzofurans & Impurities in pentachlorophenol & Plague \\
\hline Dioxin & Imputed in chlorophenols & Fish, milk, fatty tissues \\
\hline Polychlorinated biphenyls & Electrical industry & Fish, human milk \\
\hline Pentachlorophenol & Forest conversion & Fish, milk, fatty tissues \\
\hline Lead & $\begin{array}{l}\text { Emission of gases derived from } \\
\text { the use of vehicles with internal } \\
\text { combustion engine, cold combustion, } \\
\text { or manufacturing. }\end{array}$ & Vegetables, fruit \\
\hline
\end{tabular}

Source: EFSA, 2018.

In developed countries, legislation usually permits daily intake of 50-200 pg/g as toxic equivalent/person/day. According to Codex Alimentarius Commission (CAC, 2018), the highest amounts of dioxins are found in seafood (crabs, $0.36 \mathrm{pg} / \mathrm{g}$ ) and dairy (cheese, $0.38 \mathrm{pg} / \mathrm{g}$ ).

\section{Contaminants from natural sources}

Heavy metals are one of the most common categories of toxic compounds found in nature, usually as the result of irrigation, extraction and mining processes (Masindi, Muedi, 2018). Sources of contamination are usually geological, commonly found in food such are fish, soft drinks, fish-based dietary supplements, cereals, etc. Soils contaminated with heavy metals are the largest source of toxic compounds later up-taken by grown crops, or used as animal feed or directly consumed by humans. Surface water is also a reservoir of contamination in terms of heavy metals (Zhou et al., 2020), e.g. arsenic and cadmium concentrated in coal ash are being mostly ingested by fish and mammals along the food chain.

\section{Heavy metals}

Lead - it could affect serious nervous system disorders, kidney dysfunction, sterility, gout, hypertension, cardio-toxic effects, etc. The main sources of contamination are soil and water, as well as the use of lead-containing pesticides in crop production, or animal product through the used feed, while humans could be ultimately intoxicated through the consumption of contaminated plant and animal products (Jaishankar et al., 2014). Considering the fish, they do not assimilate higher concentrations of lead, but seafood does, e.g. mussels contain about 0.1-0.8 ppm. 
Cadmium - intensive exposure to cadmium could causes accumulation of toxic compounds in kidneys, shorting the average human lifespan up to 10 years (Munro, Charbonneau, 1981). As the main sources of cadmium contamination occur mining and quarrying, while the agri-food products with high concentrations could be potatoes, liver and milk.

Arsenic - it is not so often found in high concentrations in food, but rather as a chemical residue in seafood. Arsenic is capable for microbial conversion generating dimethylated compounds that certain epidemiological studies mark as the main cause of skin and lung cancer (Khairul et al., 2017).

Mercury - seafood could also contain significant amounts of mercury, including also the marine fish and aquatic vegetation. Fossil fuels combustion, incineration and smelting activities release mercury vapour into the air and it ends up as a solid in aquatic and terrestrial agricultural ecosystems. More toxic form of mercury - methyl mercury is usually found in water due conversion of soluble mercury by the bacteria. Neurological issues have been identified as a cause of human poisoning (Science for Environment Policy, 2017).

Radionuclides - anthropogenic effects are the main generators of radionuclides in nature. Agri-food products with their highest content are fruits, vegetables and processed food. Radionuclide contamination generally has regional character, and it is usually caused by natural disasters.

\section{Veterinary residues}

Another group of contaminants with the large share within the natural sources of contaminants are products used for veterinary treatments and plant protection. They carry out high concentrations of harmful chemicals, e.g. they cover more than $46 \%$ of pharmaceuticals used in animal husbandry, where $19 \%$ of them are antiinfective substances (antibiotics, antifungals and antivirals), or 13\% are anti-parasitic substances, while $11 \%$ are biological phytochemical substitutes (Hawkes, 2006). The main antibiotics used in animal husbandry are penicillin, tetracycline, streptomycin, oleandomycin, cyclosporine, etc. Antimicrobial substances can be grouped into five major classes (McKone, 1997): sulphonamides, beta-lactams, tetracyclines, aminoglycoxins and macrolides. Implementation of antibiotic treatments in animal husbandry results in their presence in higher concentrations in all animal products such are milk, eggs, meat, honey, etc. The occurrence of these inorganic compounds in food is real issue as they can increase the resistance of human bacteria to treatment and favour the transfer of pathogenic genes. 
Each stage of the agri-food chain, i.e. production, processing, distribution or marketing, could present multiple risks of contamination with toxic compounds or residues of chemical substances dangerous for humans. There are both, the potential for contamination during the phase of production, or the food processing (Perez Rodriguez et al., 2010).

The food processing is associated with physical and chemical transformation of the food products that acquire physicochemical properties leading to possible changes considered harmful to the humans (Aung, Chang, 2014).

Formation of trans-fatty acids is done through the hydrogenation of vegetable oils, which consists of saturation of molecules after reaching the melting temperature. More specifically, the saturation process leads to the solidification of the oils and their transformation into spreadable food such as margarine. Hydrogenated vegetable oil tops the list with $90 \%$ trans-fatty acids (Gupta, 2017). Some dieticians believe that hydrogenated fats offer a healthier source of fat than animal products, as they contain high amounts of saturated fat and cholesterol. This is under the question, as the ingestion of hydrogenated fats with high trans-fatty acid content significantly increases the concentration of low-density lipoprotein (cholesterol), (Dhaka et al., 2011). Balanced diet requires limitation of consumed fat, especially trans-fat. Products labelling is very important for the consumers' choice or for the modelling of consumer's behaviour, as they have to be correctly informed about that volume of dangerous hydrogenated fats contained in consumed food products.

Formation of pyrolysis products derives due tending to food preservation for as long as possible. So during the food processing it is subjected to chemical treatments. Organoleptically, preserved food changes its properties towards the denatured proteins, fats and sugars (Simforian et al., 2015). Exposing the food to temperature above $200^{\circ} \mathrm{C}$ it could be contaminated with toxic compounds with mutagenic and carcinogenic characteristics. They include polycyclic aromatic hydrocarbons and heterocyclic amines, i.e. compounds found in smoked meat, or especially vegetable oils.

Additionally, another product derived from thermal decomposition is HMF (5-hydroxymethyl-furfural), carcinogenic compound found in high fructose and invert sugar products, as well as in honey, apple juice, milk, alcoholic drinks and cigarette smoke (Kowalski et al., 2013).

In initial stages of agri-food supply chain, the raw material and food products could be contaminated with toxic and potentially carcinogenic compounds, while in further steps - storing, there is a risk that they could be contaminated with pathogens such as toxins, bacteria and viruses, continuing to endanger the human health (Bath, Moy, 1997). Whether raw materials or finished products, even properly packaged, in 
warehouses can be in contact with real source of contamination, as are fungi, moulds, etc. Thus, there does not come just to losing of the food safety, but the food itself is no longer safe for consumption. As main contaminants identified in storing process are bacteria and viruses transmitted by insects and rodents, other spoilt and mouldy products, and fungi. Contamination of foodstuff with yeasts is not considered as a biological hazard as chemical treatment of yeasts will control its usability. Hygiene and proper storing of food according to its nature, origin and category in warehouse is essential in maintaining the food safety. Improper handling by staff could lead to appearance of chemical residues caused by Staphylococcus Aureus and Clostridium Botulinum. The most common food contamination process is moulding with the formation of mycotoxins.

\section{Mycotoxins}

Mycotoxins are toxic compounds synthesised by moulds, usually found in meat, fish, peanuts and milk. Among the best known mycotoxins are aflatoxins and ochratoxin, compounds that have the ability to alter DNA, causing genetic mutations and later cancer. Cereals contain the highest amount of mycotoxins, followed by peanuts and seeds. They can transcend the whole food chain and end up in food products of animal origin (meat, milk, honey, or eggs), (Cinar, Onbasi, 2019).

In underdeveloped and poor countries, such are in Africa and South America, significant illness of population with liver cancer has been found, discovering their main cause in contamination with moulds and mycotoxins. Accordingly, certain legislative measures were imposed with restrictive policies on human or animal consumption of aflatoxin-contaminated products (Bailly, Oswald, 2013). Control measures are not easy to implement because aflatoxins are not heat-sensitive, being only a metabolic compounds of moulds and fungi. The heat treatment of food due to their decontamination can destroy moulds and spores, but not their metabolites - mycotoxins. These could be only done with chloramine and hypochloride, disinfectants for surface treatment but not suggested in food production. Several tests have shown that cattle consuming feed contaminated with mycotoxins produce contaminated milk (Martin et al., 2004). Same results have been identified in birds, as mycotoxins contaminate their muscles.

Analysing the effects of mycotoxins to human health shows that they are more dangerous than bacteria and viruses under certain conditions related to the noncompliance of food storing. Food with the highest mycotoxin content is cereals (especially corn), peanuts, oilseeds, meat and milk. 


\section{Aflatoxins}

Another group of toxic compounds synthesised by species such as Aspergillus are aflatoxins. Aspergillus species producing aflatoxins are A. Sparasiticus, A. Flavus, A. Ochraceoroseus and A. Nomius. The most species of A. Sparasiticus are aflatoxigenic, but only $35 \%$ of A. Flavus strains are aflatoxin-producing, hence there are major differences in the amounts of toxic organic compounds synthesized by Aspergillus species (Moss, 2003). The most harmful effects that aflatoxins have on living organisms are impaired liver function, decreased milk production in animals, weight loss, reduced appetite and even death. Geographically, aflatoxin-producing moulds are more prevalent in temperatecontinental areas because aflatoxins are synthesised at optimal temperatures of $35-37^{\circ} \mathrm{C}$. The most susceptible foods to aflatoxin contamination are maize and groundnuts, as they are storing at higher temperatures and humidity, affecting the conditions for the exacerbation of aflatoxin toxicity. Occurrence of aflatoxins in food is usually covered by certain legislation (Table 4.).

Table 4. Maximally permitted concentrations of aflatoxins in food products

\begin{tabular}{|l|r|r|}
\hline \multicolumn{1}{|c|}{ Food product } & \multicolumn{1}{|c|}{$\begin{array}{c}\text { Maximum } \\
\text { permitted level of } \\
\text { aflatoxin B1 } \\
\text { (mg/kg) }\end{array}$} & $\begin{array}{c}\text { Maximum } \\
\text { permitted level of } \\
\text { aflatoxin M1 } \\
\text { (mg/kg) }\end{array}$ \\
\hline $\begin{array}{l}\text { Nuts used for physical treatments or for addition as } \\
\text { ingredients in foods }\end{array}$ & 5 & 0 \\
\hline Ground and forest nuts & 8 & 0 \\
\hline $\begin{array}{l}\text { Processed hazelnut products intended for human } \\
\text { consumption as ingredient in other foods }\end{array}$ & 2 & 0 \\
\hline Dried and dehydrated fruit & 5 & 0 \\
\hline Cereals and derived products & 2 & 0 \\
\hline Maize & 5 & 0 \\
\hline Raw milk, heat-treated milk and milk powder & 0 & 0.05 \\
\hline Ginger, pepper, turmeric, nutmeg, chilli & 5 & 0 \\
\hline Cereal-based baby food & 0.1 & 0 \\
\hline Baby and infant formula & 0 & 0.02 \\
\hline
\end{tabular}

Source: EFSA, 2018.

In line to high resistance of moulds to physical and thermal treatments, aflatoxin contamination of food is even more dangerous and common than with bacteria (Van Schothorst, 2002). Risk comes from the fact that these toxic compounds end up contaminating milk, eggs and honey after feeding the animals by contaminated products, as chances for that are very high caused by storing conditions. 


\section{Ochratoxins}

Ochratoxins are toxic compounds synthesized by the mould Penicillium verrucosum in temperate-continental areas. In warm areas Aspergillus can also produce them. So, in warm areas food such as coffee, spices, cocoa and grapes could be contaminated with these compounds with a high carcinogenic risk. In recent years in Europe is found the concentration of over $0.7 \mathrm{mg} / \mathrm{kg}$ in wines and $121 \mathrm{mg} / \mathrm{kg}$ in cereals such as rye (EFSA, 2020). Ochratoxins are responsible for the development of tumours in the excretory system of animals and humans. Their presence is usually defined by legislation (Table 5.).

Table 5. Maximum permitted concentrations of ochratoxins in food products

\begin{tabular}{|l|r|}
\hline \multicolumn{1}{|c|}{ Food product } & $\begin{array}{c}\text { Maximum permitted level of ochratoxin A } \\
(\mathbf{m g} / \mathbf{k g})\end{array}$ \\
\hline Unprocessed cereals & 5 \\
\hline Dried fruit & 10 \\
\hline Roasted coffee beans & 5 \\
\hline Soluble coffee & 10 \\
\hline Wine & 2 \\
\hline Processed cereal-based foods & 0.5 \\
\hline Green coffee, beer, meat products, spices & 0 \\
\hline
\end{tabular}

Source: EFSA, 2018.

Due to the appearance of moulds, during the storing there could come to following contaminants in food products (Barra, Abe, 2021):

- Patulin that is synthesised by Penicillium, Aspergillus and Byssochlamys, does not pose a real risk for human consumption, as infected fruits could be easy identified and removed, or additionally it could be destroyed by the fermentation.

- Fumonisin B1 is synthesized by Fusarium, Moniliforme and Alternaria Alternata $\mathrm{Sp}$. Lycopersici. It is one of the most studied mycotoxins. Currently no effects of fumonisin on human health are known but in 1981 it was associated to oesophageal cancer in humans.

- Tricothecenes is synthesized by Fusarium, as highly toxic, and could be found in barley, wheat and maize.

- Deoxynivalenol is synthesized by Fusarium with lower toxicity, also found in cereals and cereal products. 
- Citrin is synthesized by Penicillium with low toxicity but with ability to proliferate at low temperature. It is usually found on the cheese.

- Scombrotoxin(Histamine) is synthesized by species of the families Pomatomidae, Scombridae, Scomberesocidae, Coryphaena. Histamine producing by fish are mackerel, sardines, and tuna.

\section{Conclusions}

In order to improve efficiency and compliance with food safety standards, the operational procedures for the entire agri-food chain involve continuously monitoring the each stage of the supply chain. Determination of food quality and safety objectives, action that will lead to easy identification of contamination risks, as to preventive and corrective measures that have to be applied in all agri-food units in case of possible contamination.

Effective food safety management system involves elimination of potential hazards, limitation of the microbial presence and ensuring the overall food safety. The best examples of farm-to-fork control measures are:

- Prevent and limit the concentration of contaminants and chemicals during processing;

- Application of good practice in veterinary medicine to limit the use of antibiotics and drug treatments that may contaminate final products with chemical residues dangerous for human health;

- Compliance with physico-chemical parameters, decontamination processes and the use of preservatives in order to reduce the concentration of hazards in food;

- Application of standardised toxicological assessment methods for chemical hazards (monitoring the presence of pesticide residues, food additives, sanitising substances, etc.);

- Proper labelling of agri-food products in order to better inform the consumers, especially people with allergies, pregnant women, children and people with immune deficiencies;

- Continuous monitoring of all processes along the production-consumption chain;

- Educate consumers and identify measures in order to encourage primary producers and processors to respect quality standards by developing proper educational programmes.

Promotion, awareness and understanding by all stakeholders involved in the food production is essential as integral part of risk analysis with the primary objective of providing consumers with meaningful, relevant and accurate information. 


\section{References}

1. Acosta, O., Chaparro, A. (2008). Genetically modified food crops and public health. Acta Biologica Colombiana, 13(3):3-26.

2. Alharbi, O., Khattab, R., Ali, I. (2018). Health and environmental effects of persistent organic pollutants. Journal of Molecular Liquids, 263:442-453.

3. Ames, B., Gold, L., Shigenaga, M. (1996). Cancer prevention, rodent high-dose cancer tests, and risk assessment. Risk Analysis, 16(5):613-617.

4. Ames, B., Profet, M., Gold, L. (1990). Dietary pesticides (99.99\% all natural). Proceedings of the National Academy of Sciences, 87(19):7777-7781.

5. Ashraf, M. (2017). Persistent organic pollutants (POPs): A global issue, a global challenge. Environmental Science and Pollution Research, 24(5):4223-4227.

6. Aslam, S., Emmanuel, P. (2010). Formulating a researchable question: A critical step for facilitating good clinical research. Indian Journal of Sexually Transmitted Diseases and AIDS, 31(1):47-50.

7. Aung, M., Chang, Y. (2014). Traceability in a food supply chain: Safety and quality perspectives. Food Control, 39:172-184.

8. Bailly, J., Oswald, I. (2013). Toxins/Mycotoxins. In: Worsfold, P., Poole, C., Townshend, A., Miro, M. (Eds.) Encyclopedia of Analytical Science, third edition, Academic Press, Cambridge, USA, pp. 129-140.

9. Barra, L., Abe, I. (2021). Chemistry of fungal meroterpenoid cyclases. Natural Product Reports. 38(3):566-585.

10. Bath, R., Moy, G. (1997). Monitoring and assessment of dietary exposure to chemical contaminants. World Health Statistics Quarterly, 50(1/2):132-149.

11. Bernstein, J., Bernstein, I., Bucchini, L., Goldman, L., Hamilton, R., Lehrer, S., Rubin, C., Sampson, L. (2003). Clinical and laboratory investigation of allergy to genetically modified foods. Environmental Health Perspectives, 111(8):1114-1121.

12. CAC (2018). Report of the $12^{\text {th }}$ Session of the Codex Committee on Contaminants in Foods. Codex Alimentarius Commission (CAC), FAO, Italy, available at: www.fao.org/fao-who-codexalimentarius/committees/cac/about/en/, retrieved at: $11^{\text {th }}$ April 2021.

13. Cinar, A., Onbasi, E. (2019). Mycotoxins: The hidden danger in foods. In: Sabuncuoglu, S. (Edt.) Mycotoxins and food safety. IntechOpen, London UK, pp. 1-21.

14. Dhaka, V., Gulia, N., Ahlawat, K., Khatkar, B. (2011). Trans-fats: Sources, health risks and alternative approach - A review. Journal of food science and technology, 48(5):534-541. 
15. Dougherty, C., Holtz, S., Reinert, J., Panyacosit, L., Axelrad, D., Woodruff, T. (2000). Dietary exposures to food contaminants across the United States. Environmental Research, 84(2):170-185.

16. EFSA (2018). Chemical contaminants. Portal of the European Food Safety Authority (EFSA), Parma, Italy, available at: www.efsa.europa.eu/en/topics/ topic/chemical-contaminants, retrieved at: $6^{\text {th }}$ April 2021.

17. EFSA (2020). Outcome of a public consultation on the risk assessment of ochratoxin A in food. Technical report no. 1845, European Food Safety Authority (EFSA), Parma, Italy, available at: https://efsa.onlinelibrary.wiley.com/doi/ abs/10.2903/sp.efsa.2020.EN-1845, retrieved at: 29 ${ }^{\text {th }}$ April 2021, p. 48.

18. FMI (1990). Trends 90: Consumer Attitudes and the Supermarket. Food Marketing Institute (FMI), Washington, USA.

19. Gaur, N., Narasimhulu, K., PydiSetty, Y. (2018). Recent advances in the bioremediation of persistent organic pollutants and its effect on environment. Journal of cleaner production, 198:1602-1631.

20. Gupta, M. (2017). Practical guide to vegetable oil processing. Second edition, Elsevier Inc., Amsterdam, the Netherlands.

21. Hahn, M. E. (2002). Biomarkers and bioassays for detecting dioxin-like compounds in the marine environment. Science of the Total Environment, 289(1-3):49-69.

22. Hawkes, C. (2006). Uneven dietary development: Linking the policies and processes of globalization with the nutrition transition, obesity and diet-related chronic diseases. Globalization and Health, 2(1):1-18.

23. Jaishankar, M., Tseten, T., Anbalagan, N., Mathew, B., Beeregowda, K. (2014). Toxicity, mechanism and health effects of some heavy metals. Interdisciplinary toxicology, 7(2):60-72.

24. Jones, K., De Voogt, P. (1999). Persistent organic pollutants (POPs): State of the science. Environmental pollution, 100(1-3):209-221.

25. Khairul, I., Wang, Q., Jiang, Y., Wang, C., Naranmandura, H. (2017). Metabolism, toxicity and anticancer activities of arsenic compounds. Oncotarget, 8(14):2390523926.

26. Kowalski, S., Lukasiewicz, M., Duda Chodak, A., Ziec, G. (2013). 5-hydroxymethyl-2-furfural (HMF): heat-induced formation, occurrence in food and biotransformation: A review. Polish journal of food and nutrition sciences, 63(4):207-225.

27. Ljunggren, S., Helmfrid, I., Salihovic, S., van Bavel, B., Wingren, G., Lindahl, M., Karlsson, H. (2014). Persistent organic pollutants distribution in lipoprotein fractions in relation to cardiovascular disease and cancer. Environment international, 65:93-99. 
28. Martin, J., Kannan, K., Berger, U., de Voogt, P., Field, J., Franklin, J., Giesy, J., Harner, T., Muir, D., Scott, B., Kaiser, M., Järnberg, U., Jones, K., Mabury, S., Schröder, H., Simcik, M., Sottani, C., van Bavel, B., Kärrman, A., Lindström, G., van Leeuwen, S. (2004). Analytical challenges hamper perfluoroalkyl research. Environmental Science and Technology, 38(13):248A-255A.

29. Masindi, V., Muedi, K. L. (2018). Environmental contamination by heavy metals. In: Saleh, H., Aglan, R. (Eds.) Heavy metals, IntechOpen, London, UK, pp. 115-132.

30. McKone, T. (1997). International Society of Exposure Analysis. Journal of exposure analysis and environmental epidemiology, 7(4):403-409.

31. Moss, M. (2003). Aflatoxins. In: Caballero, B. (Edt.) Encyclopedia of Food Sciences and Nutrition, Academic Press, Cambridge, USA, pp. 66-72.

32. Munro, I., Charbounneau, S. (1981). Environmental Contaminants. In: Roberts, H. (Edt.) Food Safety, John Wiley \& Sans, NY, USA, pp. 141-180.

33. NRC (2000). Environmental Transport and Exposure Pathways of Substances Emitted from Incineration Facilities. In: Waste Incineration \& Public Health, National Research Council (NRC), National Academies Press, Washington, USA.

34. Perez Rodriguez, F., Castro, R., Posada Izquierdo, G., Valero, A., Carrasco, E., Garcia Gimeno, R., Zurera, G. (2010). Evaluation of hygiene practices and microbiological quality of cooked meat products during slicing and handling at retail. Meat Science, 86(2):479-485.

35. Radovanovic, R. (2011). Food safety: The global problem as a challenge for future initiatives and activities. In: Hefnawy, M. (Edt.) Advances in Food Protection: Focus on Food Safety and Defence, Springer Nature, Cham, Switzerland, pp. 27-48.

36. Schmitt, C. (1998). Environmental Contaminants. In: Mac, M., Opler, P., Haeckler, C., Doran, P. (Eds.) Status and Trends of the Nation's Biological Resources, vol. 2, U.S. Department of the Interior, U.S. Geological Survey, Reston, USA, pp. 131-144.

37. Science for Environment Policy (2017). Tackling mercury pollution in the EU and worldwide. In-depth Report no. 15 made for the European Commission, DG Environment by the Science Communication Unit, UWE, Bristol, available at: http://ec.europa.eu/science-environment-policy, retrieved at: $26^{\text {th }}$ April 2021.

38. Simforian, E., Nonga, H., Ndabikunze, B. (2015). Assessment of microbiological quality of raw fruit juice vended in Dar es Salaam City, Tanzania. Food Control, 57:302-307.

39. Swanson, N., Leu, A., Abrahamson, J., Wallet, B. (2014). Genetically engineered crops, glyphosate and the deterioration of health in the United States of America. Journal of Organic Systems, 9(2):6-37. 
40. Van Schothorst, M. (2002). Microbiological risk assessment of foods in international trade. Safety Science, 40(1-4):359-382.

41. WHO (2020). Food safety: Key facts. Portal of the World Health Organization (WHO), Geneva, Switzerland, available at: www.who.int/news-room/factsheets/detail/food-safety, retrieved at: $6^{\text {th }}$ April 2021.

42. Young, I., Waddell, L., Wilhelm, B., Greig, J. (2020). A systematic review and meta-regression of single group, pre-post studies evaluating food safety education and training interventions for food handlers. Food Research International, 128(108711):1-8.

43. Zeiger, E. (1997). Genotoxicity Database. In: Gold, L., Zeiger, E. (Eds.) Handbook of Carcinogenic Potency and Genotoxicity Databases, CRC Press, Boca Raton, USA, pp. 687-729.

44. Zhou, Q., Yang, N., Li, Y., Ren, B., Ding, X., Bian, H., Yao, X. (2020). Total concentrations and sources of heavy metal pollution in global river and lake water bodies from 1972 to 2017. Global Ecology and Conservation, 22(e00925):1-11. 